\title{
Hoverfly Glutathione S-Transferases and Effect of Brassicaceae Secondary Metabolites
}

\author{
Nicolas Vanhaelen ${ }^{(1)}$, Eric Haubruge ${ }^{(1)}$, Georges Lognay ${ }^{(2)}$, and Frédéric Francis ${ }^{(1)}$ \\ (1) Pure and Applied Zoology Unit, Gembloux Agricultural University, B-5030 Gembloux, Belgium \\ (2) Unit of General and Organic Chemistry, Gembloux Agricultural University, B-5030 Gembloux, \\ Belgium
}

\begin{abstract}
The Episyrphus balteatus hoverfly is commonly found in very diversified biotopes including Brassicaceae crop fields. Glutathione S-transferases (GST) are detoxification enzymes that are involved in the metaboliza-tion of plant allelochemicals such as glucosinolates and related volatile products (mainly isothiocyanates) from Brassica plants. Developmental expression of E. balteatus glutathione S-transferases was studied. With regard to the high level of glutathione S-transferase activity in syrphid adults, the latter stage was also used to assess the glutathione S-transferase distribution in several parts of the insect. Higher glutathione S-transferase activities were found in the thorax (47.5 and 38.5\%) followed by the abdomen (32.4 and 32.9\%) and the head (20.4 and $28.5 \%$ ) with 1-chloro-2,4-dinitrobenzene, and 2,4-dinitro-1-iodebenzene, respectively. Analysis of Brevicoryne brassicae, the cabbage aphid, by GC-MS revealed the presence of isothiocyanates. The latter are the main degradation products of the glucosinolate from the host plant at neutral $\mathrm{pH}$. Feeding the predators with this aphid species and with the generalist Myzus persicae reared on Brassica napus induced glutathione S-transferase activity. Impact of volatiles from the host plant on the glutathione S-transferase activity was also determined by exposure of syrphid larvae to isothiocyanates (allyl- and benzyl-isothiocyanates). Enzyme inductions were observed only from a 1 ppm concentration. Enzymatic activity evolution was discussed as an adaptation to cope with allelochemicals from plants. Finally, the glutathione 5-transferase activities of several hoverfly species were compared in relation to their feeding behavior (coprophagous, saprophagous, and aphidophagous) at the larval stages. The results seem to indicate quantitative and qualitative differences of glutathione S-transferases according to the feeding behavior of the larvae.
\end{abstract}

Key Words: glutathione S-transferase; Brevicoryne brassicae; Myzus persicae; hoverflies; plant allelochemical; chemical ecology.

\section{INTRODUCTION}

Glutathione S-transferases (GST; EC 2.5.1.18) are mainly cytosolic enzymes that catalyze the conjugation of electrophile molecules with reduced glutathione (1). When conjugated to reduced glutathione (GSH), potentially toxic substances become more water soluble and generally less toxic (2). GSTs play an important role in insecticide resistance and are involved in die metabolism of organophosphorous and organo-chlorine compounds (3-6). Other xenobiotics such as plant defence allelochemicals against phytophagous insects induce GST activity (7). Glucosinolates and their degradation products (mainly isothiocyanates (ITC)) are Brassicaceae secondary metabolites and induce GST activity in Myzus persicae Sulzer and several Lepidop-tera species $(8,9)$. The influence of plant allelochemicals is not limited to the herbivores; specialized phytophagous insects such as the lupin aphid, Macrosiphum albifrons Essig, can also use them as defence substances, which affect pest predator biology (10). High mortality rates were observed when the two-spot ladybird, Adalia bipunctata L., was fed with aphids reared on Brassicaceae species (11). Increasing GST activity was detected in surviving ladybirds and was correlated with increasing glucosinolate concentrations in the prey host plant (12).

Larvae of Episyrphus balteatus De Geer were commonly found to feed on B. brassicae colonies (13), participating in the reduction of aphid populations in cabbage fields (14). Here, we investigated the GST system in a hoverfly species to study the aphidophagous predator adaptation to the presence of allelochemicals (glucosinolates and isothiocyanates) originating from the host plant or through the prey. The GST activity expression was studied at each developmental stage and the enzyme distribution in adults was determined. Then, we focused on the impact of the secondary plant compounds by feeding hoverfly larvae with aphids reared on Brassica plants. Exposures of larvae to ITC were also performed to confirm the effect of these volatiles. Finally, potential relations between the feeding behavior of syrphid species at the larval stage and their GST activities 
were studied with two benzene substrates.

\section{MATERIALS AND METHODS}

\section{Chemicals}

1-Chloro-2,4-dinitrobenzene (CDNB) and 2,4-dinitro-1-iodobenzene (DNIB) were prepared in ethanol in $20 \mathrm{mM}$ solutions. Reduced glutathione was used as distilled water solution at $100 \mathrm{mM}$. All products were purchased from Fluka Chemical and Vel Co. Allyl- and benzyl-isothiocyanates were purchased from Aldrich Chemical Co. and prepared in ethanol solutions.

\section{Plants and Insects}

Broad beans (Vicia faba L.) were grown in $20 \mathrm{X} 30$-cm trays including a mixture of perlite and vermiculite (1/1) in a controlled environment room at $20 \pm 2{ }^{\circ} \mathrm{C}$ and 16 -h daylight photo-period. Oilseed rape (Brassica napus L.) were raised in 10-cm-diameter plastic pots containing ordinary compost in separated rooms with the same controlled conditions. While Megoura vic-iae Buckton (Homoptera: Aphididae) were reared on broad beans and used as hoverfly control diet, crucifer species was used as B. brassicae and M. persicae host plant. Each aphid species had been reared in the laboratory in separated rooms for several years.

The first generation of E. balteatus was provided by PK Nutzlingzuchten (Welzheim, Germany). Adults were reared in $100 \times 60 \times 60-\mathrm{cm}$ cages and fed with pollen, honey, and sugar. Hoverfly larvae were mass-reared in aerated plastic boxes of $11 \times 14 \times 4 \mathrm{~cm}$ and were fed daily ad libitum with $M$. viciae as standard diet. In the same kind of box, 10 larvae were offered B. brassicae and M. persicae reared on B. napus for $24 \mathrm{~h}$ to test the allelochemicals impact on the GST activity.

The other hoverfly species were caught with a net in the botanical garden of the Gembloux University.

\section{Hoverfly Larvae Expositions to Volatile Isothiocyanates}

Ten hoverfly larvae were exposed to ITC in 800-ml glass dessiccators for $24 \mathrm{~h}$. Ten microliters of ITC solutions in ethanol were applied before the hermetic containers were closed.

\section{Determination of Protein Concentration and Glutathione S-Transferase Activity}

The GST activity was determined according to Habig et al. (15) with a $20 \mathrm{mM}$ phosphate buffer, $\mathrm{pH} 6.8$. The protein concentration of homogenates was determined by the method of Lowry et al. (16). Two replicates were used for each experiment. Serial dilutions of bovine serum albumin were used for the construction of a standard curve that provided the extinction coefficient. A Shimadzu UV-160A spectrophotometer was used for protein and enzymatic measurements.

\section{Glucosinolate Hydrolysis Product Analysis}

The $B$. brassicae aphids (250 mg) reared on B. napus were first crushed in $2 \mathrm{ml}$ of phosphate buffer, $\mathrm{pH} 6.8$, and maintained for $30 \mathrm{~min}$ at $30 \pm 0.2^{\circ} \mathrm{C}$ in a thermostated water bath. The glucosinolate degradation products from aphid samples were extracted with $500 \mu \mathrm{l}$ pure diethyl ether for $2 \mathrm{~h}$. The solutions were injected as such in the splitless injector with a Hewlett-Packard GC-MS system (HP5972 mass spectrometer coupled to a HP5890

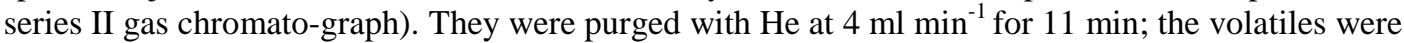
concentrated at room temperature on a Vocarb 3000 and finally desorbed by flash-heating to $250^{\circ} \mathrm{C}$. The molecules of interest were automatically transferred to the GC-MS through a split-splitless injector at $250^{\circ} \mathrm{C}$ (splitless mode). They were separated on a HP5-MS (5\% phenyl-dimethylpolysilox-ane) column (30 m x 0.25 $\mathrm{mm}, \mathrm{df}=1 \mu \mathrm{m})$. The temperature program was from $40^{\circ} \mathrm{C}(1 \mathrm{~min}$ hold $)$ to $180^{\circ} \mathrm{C}$ at $6^{\circ} \mathrm{C} \mathrm{min} \mathrm{m}^{-1}$ and then to $280^{\circ} \mathrm{C}$ at $15^{\circ} \mathrm{C} \mathrm{m^{-1 }}$. The MS spectra were obtained in the El mode at $70 \mathrm{eV}$ (scanned mass range from 30 to $300 \mathrm{amu}$ ). The analytes were identified on the basis of their retention times and by interpretation of MS fragmentation patterns. The recorded spectra were Finally compared to those of the Wilcy238.L spectral library.

\section{Data Analysis}

All results were analyzed by ANOVA followed by mean comparison tests by the least significant difference method when needed. Minitab software (Vs 11.2) (17) was used for the data analysis. 


\section{RESULTS}

GST expression of the first larval stage was not analyzed due to the small size of the larvae; the individual measurement was not possible. The second and third larval stages showed quiet low activity levels (Fig. 1). A sharp increase of the GST activity was observed in pupae, with an activity five- to eight-fold higher than that observed for the third larval stage. Adult GST activity was similar to the level reached by the pupae.

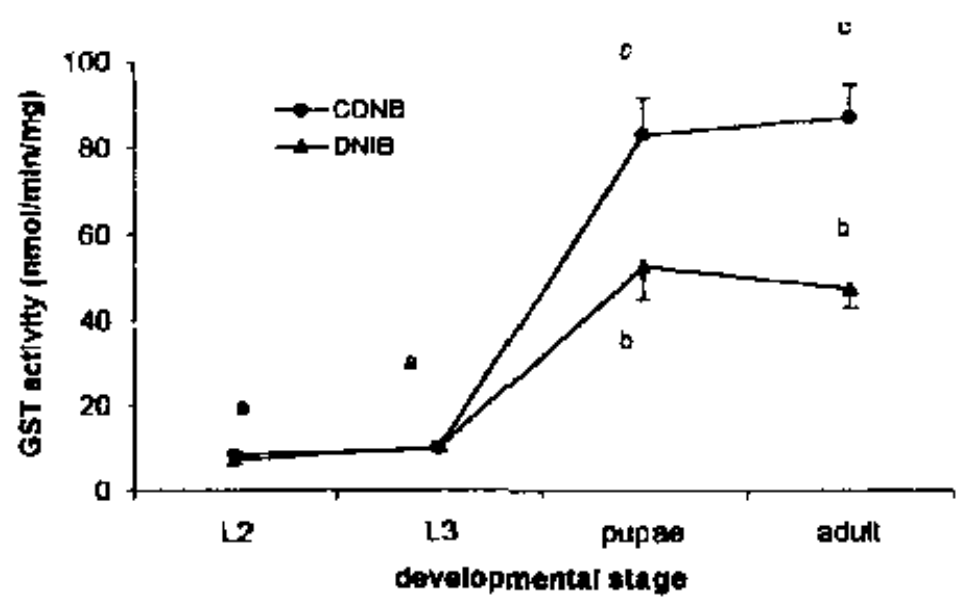

FIG. 1. Glutathione S-transferase expression toward CDNB and DNIB with developmental stages of Episyrphus balteatus. Error bars represent standard errors $(n=10)$. Letters indicate significant difference at $P=0.05$.

Adults of E. balteatus were selected to investigate the GST activity distribution (Table 1). Most of the activity (47.2 and 38.5\% with CDNB and DNIB, respectively) was found in the thorax, regardless of the benzene substrate used. The abdomen also showed high levels of GST activity (32.4 and 32.9\% with CDNB and DNIB, respectively) and lower amounts were observed in the head.

When fed for the first 4 days with the control diet and changed to M. persicae or B. brassicae, both reared on $B$. napus, the two latter preys increased the hoverfly GST activity toward CDNB but no variation of enzymatic activity was observed toward DNIB ( $F=38.54, P<0.001 ; F=3.20, P=0.077$, respectively) (Fig. 2). The occurrence of only glucosinolates in $M$. persicae and of both glucosinolates and ITC in B. brassicae prey was already detected (18). Two B. napus glucosinolate degradation products, namely pent-4-enyl-ITC and phenylethyl-ITC, were found in B. brassicae when it was reared on the latter host plant (Fig. 3). Feeding the hoverfly with aphid reared on B. napus increased 1.4- and 2.0-fold the GST activity toward CDNB for M. persicae and $B$. brassicae, respectively, compared to control diet $(t=3.92, P=0.001 ; t=8.47, P<0.001$, respectively). To confirm the role of Brassicaceae allelochemical influence on GST activity, the larvae were exposed to allyl- and benzyl-ITC, which had an impact on the detoxification enzyme of the hoverfly. GST activity toward CDNB (Fig. 4) increased from a 1-ppm benzyl-ITC concentration when compared to the control $(\mathrm{F}=10.62, P<0.001)$. Significant differences of GST activity were observed for the ITC tested concentration range $(t=2.14, P=$ $0.045 ; t=3.75, P=0.001 ; t=3.66, P=0.001$, for 1,2 , and $3 \mathrm{ppm}$, respectively). Differences were also significant between 0.5 and 2 or $3 \mathrm{ppm}(t=2.10, P=0.048 ; t=2.56, P=0.019$, respectively), and between 1 and $3 \mathrm{ppm}(t=2.32, P=0.031)$, but not between 2 and $3 \mathrm{ppm}(t=1.16, P-0.199)$. 
TABLE 1 Distribution of the Glutathione S-Transferase Activity in Adults of Episyrphus balteatus toward CDNB and DNIB

Distribution (\%)

\begin{tabular}{llllc}
\cline { 2 - 5 } Insect body part & \multicolumn{2}{c}{ CDNB } & Mean & SE \\
\cline { 2 - 5 } & Mean & SE & $28.5 \mathrm{a}$ & 3.9 \\
Head & $20.4 \mathrm{a}$ & 3.8 & $38.5 \mathrm{a}$ & 3.9 \\
Thorax & $47.2 \mathrm{ab}$ & 4.3 & $32.9 \mathrm{a}$ & 3.3 \\
Abdomen & $32.4 \mathrm{~b}$ & 0.6 & 100 & - \\
Whole body & 100 & - & & \\
& Specific activity $(\mathrm{nmol} / \mathrm{min} / \mathrm{mg})$ & $43.05 \mathrm{a}$ & 6.81 \\
Head & $46.89 \mathrm{a}$ & 6.15 & $60.01 \mathrm{a}$ & 8.37 \\
Thorax & $118.25 \mathrm{ab}$ & 18.59 & $47.35 \mathrm{a}$ & 3.49 \\
Abdomen & $78.61 \mathrm{~b}$ & 4.78 & 44.14 & 2.13 \\
Whole body & 90.66 & 4.87 & & \\
\hline
\end{tabular}

Note. Mean $(\mathrm{n}=10)$ values are followed by standard errors $(\mathrm{SE})$. Means within a column followed by the same letter are not significantly different from each other at $P-0.05$.

Allyl-ГГC significantly influenced the GST activity of $E$. balteatus $(F=5.46, P=0.005)$. No activity difference between control and $0.5,1$, and 2 ppm was observed $(t=0.50, P=0.348 ; t=1.33, P=0.163 ; t=1.38, P=$ 0.153 , respectively). The GST activity related to $1 \mathrm{ppm}$ allyl-ITC was significantly lower than that corresponding to $2 \mathrm{ppm}(t=2.80, P=0.011)$. Higher concentrations of allyl-ITC induced the death of all larvae exposed to the volatile. Neither allyl-ITC nor benzyl-ITC influenced the GST activity of E. balteatus toward DNIB (Fig. 4) $(F=2.94, P=0.067 ; F=1.56, P=0.207$, respectively).

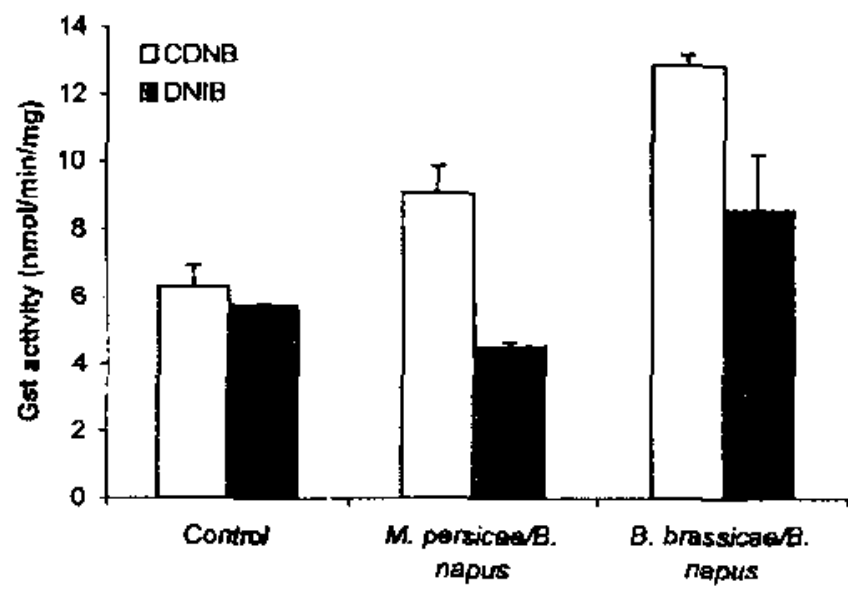

FIG. 2. Glutathione S-transferase activity (mean $\pm S E, n=10$ ) of E. balteatus fed with several aphid and host plant combinations for $24 \mathrm{~h}$. Megoura viciae reared on Vlcia faba is the control diet. 
The GST activity of different syrphid species was investigated in relation to the feeding behavior at their larval stage (Table 2). Aphidophagous predators showed higher GST activities toward CDNB, but not toward DNIB, than the coproph-agous and saprophagous species $(t=2.74, P=0.018 ; F=0.59, P=0.459$, respectively). The most interesting result was the observation of a constant ratio between GST activity toward CDNB and toward $\operatorname{DNIB}(t=6.33, P<0.001)$.

\section{DISCUSSION}

Before assessing the impact of allelochemi-cals on E. balteatus GST, we investigated the hoverfly detoxification system. GST activities were compared following the developmental stage: the enzymatic activity increased from the larvae to the adult, with a five- to eight-fold increase from the larvae to the pupae. These observations were in accordance with previous studies on the housefly Musca domestica L. (19) and on A. bipunctata (20). In Tenebrio molitor L., the activity increased from larvae to pupae and decreased in the adult (21). The localization of the GST activity was studied in adult hoverfly due to the high amount of enzyme found in this

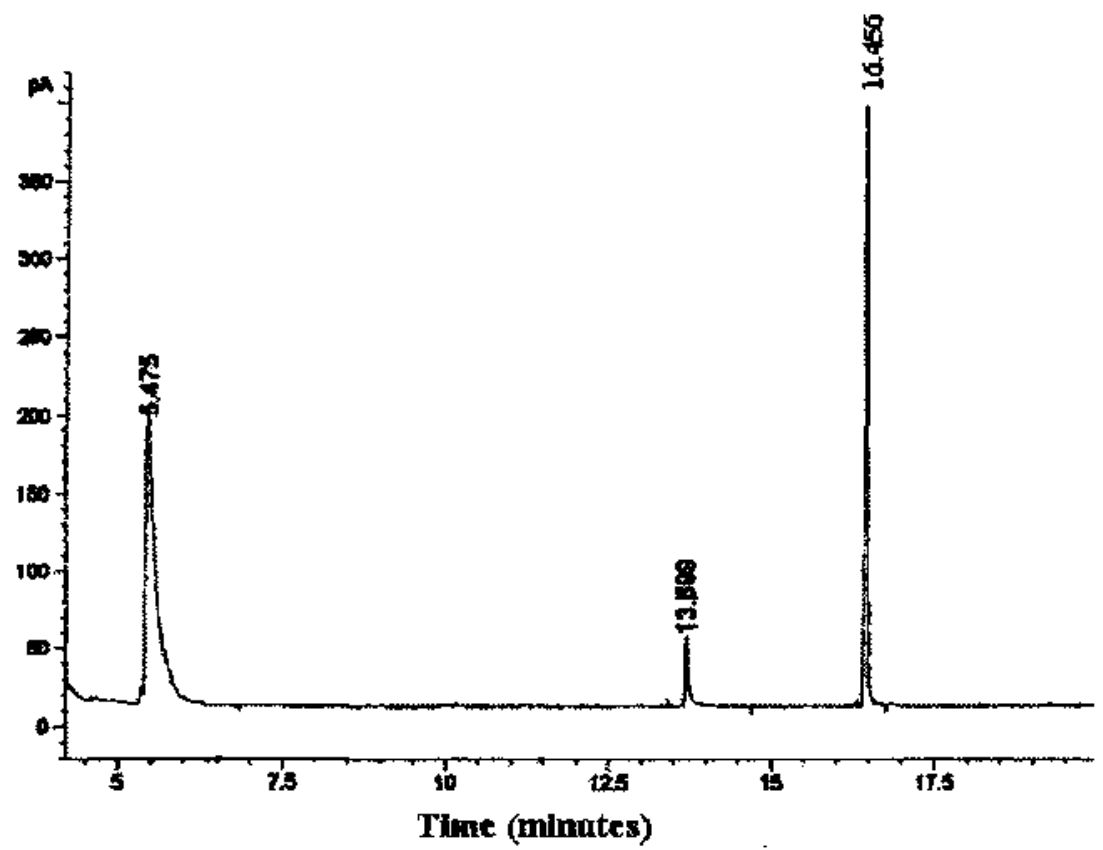

FIG. 3. GC-MS chromatogram (total ion current) of a diethyl ether extract of Brevicoryne brassicae reared on Brassica napus ( $R t=5.47$ : pent-4-enyl-ITC; $R t=13.69$ : phenyl-ethy-ITC; $R t=16.45:$ butylated hydroxytoluene).

developmental stage. With both benzene substrates, CDNB and DNIB, the thorax showed the highest GST activity followed by the abdomen and the head. In previous studies on A. bipunctata (20) and the housefly (19), most of the GST activity was found in the abdomen. The study of the GST microscopic repartition in Shistocerca gregaria Forksal showed that the highest GST activity was found in the Malpigh-ian tubes, the fat body, and the midgut (22). Nevertheless, the general GST activity pattern of E. balteatus corresponded to the localization of the GST two isoforms in M. domestica and Drosophila melanogaster Meigen that appear mainly in the wing muscles, although their detoxification roie was not established $(23,24)$. Syrphid larvae feeding on Brassicainfesting aphids have to permanently cope with the secondary substances from the plant, the glucosino-lates and related degradation products when the plant was damaged, or through their prey. Whereas the generalist $M$. persicae reared on mustards contained only glucosinolates, the specialist $B$. brassicae also produced ITC compounds due to its endogenous myrosinase (18). To test the impact of some glucosinolates and their derivatives on the hoverfly GST, syrphid larvae were fed with $M$. persicae and B. brassicae reared on $B$. napus for $24 \mathrm{~h}$. These diets increased 1.4- to 2-fold the insect GST activity toward CDNB, whereas no significant variation was observed toward DNIB. To confirm the inducer role of ITC, syrphid larvae were exposed to allyland benzyl-ITC which were previously selected for their role on the GST activity $(25,26)$. Our results indicated that ITC induced one of the E. balteatus detoxification enzymes. The higher induction of GST by benzyl-ITC had already been reported for human and rat cells and is likely to be due to the compound structure (27). 


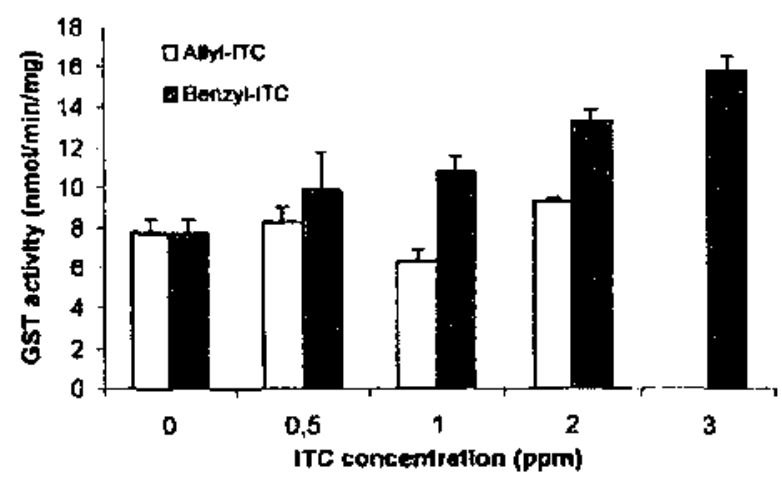

b

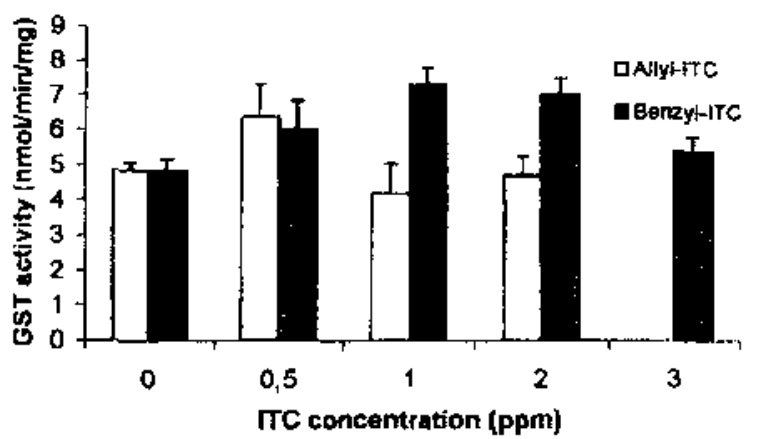

FIG. 4. Glutathione S-transferase activity of Episyrphus balteatus exposed to benzyl-ITC and allyl-ITC toward CDNB (a) and DNIB (b). Error bars represent standard errors (n ranges from 7 to 10 ).

The effect of Brassicaceae secondary metabolites on the GST activity was also studied in A. bipunctata (12). The increased GST activity was described as an adaptation to the allelochemical presence in the plant or in the prey. Indeed, herbivores sequestrate plant secondary metabolites as defence against their predators (28). Such a use of allelochemicals has already been reported for several aphid species: alkaloids from Lupinus sp. by M. albifrons, cardenolides by Aphis nerii Boyer de Foscolombe, and the glucosinolates and their derivatives by B. brassi-cae $(18,29,30)$.

To compare the E. balteatus GST responses to CDNB and DNIB with those of other hoverflies, several syrphid species were tested for differential adaptations, which could result from the feeding behavior of the larvae. The GST activities of individuals from aphido-, sapro-, and coprophagous species were compared. Higher GST levels were observed in aphidophagous species and could be interpreted as an adaptation to cope with defensive compounds emitted by plants or sequestrated by their prey, as already mentioned above. Another hypothesis for the occurrence of high amounts of detoxification enzyme in aphidophagous syrphids could be linked to the species habitat. Aphidophagous species tested are frequently or almost exclusively found in farmland (31). This species might thus often be exposed to pesticides, which are known to induce GST activity (32-34).

Nevertheless, some habitats of saprophagous and coprophagous species might also contain organic compounds and pollutants that could necessitate strong detoxification abilities. Species such as Eristalis spp. have larvae that develop in stagnant and filthy water (35), which could contain potential GST inducers (4).

The most striking observation related to the larval diet was the constant ratio between activities toward CDND and activities toward DNIB, which were almost twice as high in the syrphini species as in the other species. This observation suggested that, more than the GST amounts, the isoenzyme patterns varied for the aphidophagous compared to the others. Indeed, different activity patterns against at least two substrates indicate the existence of multiple isoenzymatic forms. The range and extent of detoxification depend on the number of specific isozymes (21). The feeding habit influence on nature and amount of GST had already been demonstrated with herbivores. The specialists Heliothis virescens Fab., Trichopulsia ni Hubner, and Anticarsia gemmatalis Hubner possess only one GST form, whereas the polyphagous Spodoptera frugiperda Smith and Heliothis zea Boddie have six and four isoenzymes, respectively (36). The diet itself also plays a role in isoenzymatic expression. The subunit 
3 of GST 2 from Orthosia gothica L. was present when they were fed bean diet since hatching but not when this feed was introduced to apple-leaf feeders in the third instar (37).

To determine more accurately the GST isoenzyme specificities of E. balteatus and the potential role in plant allelochemical detoxification, the purification of the hoverfly GST must be performed. Only coupled biochemical and biological studies will allow a better understanding of multitrophic interactions such as plantaphid- hoverfly predator relations. This kind of study will enhance the improvement of integrated pest management in crop plants including allelochemicals, such as the Brassicaceae species, by determining the adaptation and the coevolution of pest and beneficial insects to some plants and not to others.

TABLE 2 Glutathione S-Transferase Activity of Different Syrphid Species in Relation to the Feeding Habit of Their Larvae $(n=10)$

\begin{tabular}{|c|c|c|c|c|c|c|}
\hline \multirow[b]{3}{*}{ Tribe and syrplad species } & \multicolumn{4}{|c|}{ (oST specilac activily (numol/min/mg) } & \multirow{3}{*}{$\begin{array}{l}\text { Ratio, } \\
(1 / 2)\end{array}$} & \multirow{3}{*}{$\begin{array}{c}\text { Foeding haluit of } \\
\text { the larvate }\end{array}$} \\
\hline & \multicolumn{2}{|c|}{ CDNB (1) } & \multicolumn{2}{|c|}{ DNTB $(2)$} & & \\
\hline & Meín & sis & Mcan & SE & & \\
\hline \multicolumn{7}{|l|}{ Sугрhıпі } \\
\hline 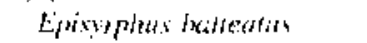 & 9.567 & 4.87 & 47.21 & 0.90 & 2.03 & Aplaidepletigous \\
\hline Sonevepraisi & $62,6,5$ & 5.24 & 35.47 & 7.36 & 1.7 .1 & Aplidophayous \\
\hline Symplus ribesio & 48.49 & 2.21 & 20.0 .5 & 2.35 & 2.42 & Aplifikoplaigge(is \\
\hline Syrphus vitrijomis & 96.64 & 7.44 & 30.35 & 3.67 & $\therefore 40$ & Aphidephagous \\
\hline Spinatopinotia scripa & 114.77 & 7.38 & 47.11 & 3.98 & 2.44 & Aphidephitgous \\
\hline 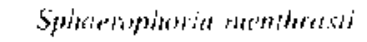 & 11247 & 8.50 & $438 ?$ & 1.35 & 2.57 & Aphidephagous \\
\hline \multicolumn{7}{|l|}{ Eristalini } \\
\hline Eristalis abostorum & 61.48 & 7.09 & 58.23 & 5.87 & 1.06 & Sapro-, coprophagous \\
\hline Eristulis nemomum & 71.41 & 6.36 & $\$ 2.84$ & 5.47 & 1.35 & Sapro-, eoproplangous \\
\hline Eristalis pentinax & 61.27 & 7.41 & 38.72 & 1.72 & 1.58 & Sipro-, topropladgors \\
\hline Eristeritis lenas & 46.56 & 597 & 37.55 & 3.22 & 1.24 & Supro-, coprophagow \\
\hline \multicolumn{7}{|l|}{ Cheilosini } \\
\hline Riningia complostris & 52.8 .3 & $2.3 !$ & 36.58 & 1.11 & 1.44 & Coprophagous \\
\hline \multicolumn{7}{|l|}{ Xylotini } \\
\hline Srritta pipiens: & .39 .79 & 2.58 & 36.15 & 1.62 & 1.10 & Saprophagous \\
\hline
\end{tabular}

\section{ACKNOWLEDGMENT}

This work was supported by a PhD grant to the first author, awarded by the Fonds pour la formation a la Recherche dans l'industrie et l'Agriculture.

\section{REFERENCES}

1. K. Boyland and L. K Chasseaud, The role of glutathione and glutathione $S$-transferases in mercapturic acid biosynthesis, Adv. Enzymol 32, 173 (1969).

2. D. F. Grant and F. Matsumura. Glutathione S-transferase 1 and 2 in susceptible and insecticide resistant Aedes aegypti, Pestic. Biochem. Physiol. 33, 132 (1989).

3. A. G. Clark and N. A. Shamaan, Evidence that DDT-dehydrochlorinase from the housefly is a glutathione Stransferase. Pesiic. Biochem. Physiol. 22,249(1984).

4. A. G. Clark. The comparative enzymology of the glutathione .S-transferase from non-vertebrate organisms. Conp. Biochem. Physiol. 92 B. 419 (1989).

5. D. Fournier. .J. M. Bride, M Poirie. J. B. Bergé. and F. W. Plapp. Insect glutathione S-transferases, J. Biol. Chem. 267, 1840 (1992).

6. H. Ranson, L. A. Prapamthadara, and J. Hemingway, Cloning and characterisation of two glutathione S-transferases from a DDT-resistant strain of Anopheles gam-biae. Biochem. J. 324. 97 (1997). 
7. S. J. Yu. Host plant induction of glutathione S-trans-ferase in the fall armyworm. Pest. Biochem. Physiol. 17, 59 (1982).

8. E. Egaas. N O Svendsen, S. Kobro. J. U. Skaare, and E. G. Jensen. Activities and properties of xenobiotic metabolising enzymes on the peach potato Aphid (Myzus persicae Sulzer) feeding on paprika (Capsicum annuum L.) or swedes (Brassica napus rapifera Metzger), Comp. Biochem. Physiol. 99, 105 (1991).

9. R. W. Wadleigh and S. J. Yu. Detoxification of isothio-cyanates allelochemicals by glutathione transferase in three lepidopterous species, J. Chem. Ecol. 14, 1279 (1988).

10. B. H. Emrich, Erworbene Toxizität bei der Lupinenblat-tlaus Macrosiphum albifrons und ihr Einfluss auf die aphidophagen Prädatoren Coccinella septempunctata, Episyrphus balteatus und Chrysoperla carnea, Z. Pflanzenkrank. Pflanzenschutz. 98, 398 (1991).

11. F. Francis, E. Haubruge. and C. Gaspar, Influence of host plants on specialist/generalists aphids and on the development of Adalia bipunctata (Coleoptera; Cocci-nellidae). Eur. J. Entomol 97. 481 (2000).

12. F. Francis, Conséquences évolutives des relations entre le puceron et son prédateur en presence de substances allélochimiques chez les Brassicaceae, 5ème Conférence Internationale sur les Ravageurs en Agriculture, Annates ANPP, Tome II, 503 (1999).

13. A. E. F. Chandler, The relationship between aphid infestation and oviposition by aphidophagous Syrphidae (Diptera), Ann. Appl. Biol. 61, 425 (1968).

14. S. Vidal, Factors influencing the population dynamics of Brevicoryne brassicae in undersown Brussels sprouts, Biol. Agric. Hortic. 15, 285 (1997).

15. W. H. Habig, M. J. Pabst, and W. B. Jakoby, Glutathione S-transferases: The first enzymatic step in mercapturic acid formation, J. Biol. Chem. 249, 7130 (1974).

16. O. H. Lowry, N. J. Rosebrough, A. L. Farr, and R. J. Randall, Protein measurement with the folin phenol reagent, J. Biol Chem. 189, 193 (1951).

17. Minitab Version 11.2, Minitab Inc., State College, PA, 1998.

18. F. Francis, G. Lognay, J. P. Wathelet, and E. Haubruge, Effects of allelochemicals from first (Brassicaceae) and second (Myzus persicae \& Brevkoryne brassicae) trophic levels on Adalia bipunctata, J. Chem. Ecol. 27, 243 (2001).

19. M. A. Saleh, N. Montoyoma, and W. C. Dauterman, Reduced glutathione in the housefly: Concentration during development and variations in strains, Insect B'to-chem. 8, 311 (1978).

20. F. Francis, D. Broon, and E. Haubruge, Studies of the glutathione S-transferases activities and their localisation in Adalia bipunctata (Coleoptera: Coccinellidae), Med. Fac. Landbouww. Univ. Gent 64, 349 (1999).

21. I. Kostaropoulos, A. E. Mantzari, and A. I. Papado-poulos, Alterations of some glutathione S-transferase characteristics during the development of Tenebrio mol-itor (Insecta: Coleoptera), Insect Biochem. Mol. Biol. 26, 963 (1996).

22. Y Konno and T. Shishido, Distribution of the glutathione S-transferase in insect tissues, Appl. Entomol. Zool. 27, 391 (1992).

23. H. Franciosa and J. B. Bergé, Glutathione S-tranferases in housefly (Musca domestica) location of GST-1 and GST-2 families, Insect. Biochem. Mol. Biol. 21, 353 (1994).

24. J. D. Clayton, R. M. Cripps, J. C. Sparrow, and B. Bullard, Interaction of troponin-H and glutathione $S$ transferase-2 in the indirect flight muscles of Drosophila melanogaster, J. Muscle Res. Cell Motil. 19,117 (1998). 
25. R. H. Holm, U. H. Danielson, Y. Zhang, P. Talalay, and B. Mannervick, Isothiocyanates as substrates for human glutathione transferases: Structure-activity studies, Biochem. J. 311, 453 (1995).

26. Y Nakamura, H. Ohigashi, S. Masuda, A. Murakami, Y Morimitsu, Y. Kawamoto, T. Osawa, M. Imagawa and K. Uchida, Redox regulation of glutathione S-trans-ferase induction by Benzyl isothiocyanates: Correlation of enzyme induction with the formation of reactive oxygen intermediates. Cancer Res. 60, 219 (2000).

27. Y Nakamura, Y. Morimitsu, T. Uzu, H. Ohigashi, A. Murakami, Y. Naito, Y Nakagawa, T. Osawa, and K. Uchida, A Glutathione 5-transferase inducer from papaya: Rapid screening, identification and structure relationship of isothiocyanates, Cancer Lett. 157, 193 (2000).

28. I. B. Harborne, "Introduction to Ecological Biochemistry," p. 319, 4th ed. Academic Press, London, 1993.

29. M. Wink, and P. Römer, Acquired toxicity-The advantage of specialising on alkaloid rich lupins to Macrosi-phum albifrons (Aphididae), Naturwissenschaften 73, 210 (1986).

30. S. B. Malcolm, Chemical defence in chewing and sucking insect herbivores: Plant derived cardenolides in the monarch butterfly and oleander aphid, Chemoecology 1, 12 (1990).

31. E. Branquart, "Life-History Strategies of Hoverflies with Predacious Larvae (Diptera: Syrphinae)," p. 150, $\mathrm{PhD}$ thesis, Agricultural University of Gembloux, 1999.

32. A. G. Clark, N. A. Shamaan, M. D. Sinclair, and W. C. Dauterman, Insecticide metabolism by multiple glutathione S-transferases in two strains of the housefly, Musca domestka (L.), Pestic. Biochem. Physiol. 25, 169 (1986).

33. J. Hemingway, J. Miyamoto, and P. R. J. Herath, A possible novel link between organophosphorous and DDT insecticide resistance genes in Anopheles supporting evidence from fenitrothion metabolism studies, Pestic. Biochem. Physiol. 39, 49 (1991).

34. I. Kostaropoulos, A. I. Papadopoulos, A. Metaxakis, E. Boukouvala, and E. Papadopoulou-Mourkidou, Glutathione S-transferase in defence against pyretroids in insects. Insect. Biochem. Mol. Biol. 31,313 (2001).

35. F. S. Gilbert, "Hoverflies," p. 66, Cambridge Univ. Press, Cambridge, UK.

36. S. J. Yu, Purification and characterization of glutathione transferases from five phytophagous Lepidoptera, Pestic. Biochem. Physiol. 35, 97 (1989).

37. E. Egaas, Propiconazoie and dietary components as specific inducers of glutathione S-transferase in Orthosia gothka, Pestic. Biochem. Physiol. 53, 42 (1995). 